\title{
Factors influence to entrepreneurial team performance
}

\author{
Eang Youhouy \\ Nanjing University of Science and Technology, Xiaolingwei Street, Nanjing, China \\ eangyouhouy@yahoo.com
}

Keywords: Entrepreneurial team, Performance, Influencing factor, Evaluation method

\begin{abstract}
Entrepreneurship has always been a core source of vitality and competitiveness for the world's most powerful economies, and it is also true for China. This paper summarizes the research results of entrepreneurial team's performance for both domestic and international in term of the basic concepts, measurement indicators and methods of entrepreneurial team performance. This paper also put forward the shortcomings of China's research and future research directions through the combination of domestic and international research results.
\end{abstract}

\section{Introduction}

Entrepreneurial activities have flourished on global scale, which has greatly promoted technological progress, economic development and employment opportunities growth with the advent of entrepreneurial economy. Therefore, the issue of entrepreneurship and its performance has also attracted widespread attention from scholars in different disciplines such as economics, management, and sociology. As a result, in-depth study of entrepreneurial performance theory and the influencing factors of entrepreneurial performance, measurement indicators and evaluation methods are great significance for both development of entrepreneurial theories and deepening of entrepreneurial practices. Based on the literature review, this article will summarizes the influencing factors, measurement indicators, evaluation methods of the entrepreneurial team's performance, and analyze the shortcomings of the existing research and future research directions.

\section{Entrepreneurial team and its performance}

\subsection{The meaning of entrepreneurial teams and its performance}

The U.S. economy grew rapidly after the second U.S. oil crisis; the famous management master, Peter Drucker, called this prosperity an "entrepreneurial economic system." Since then, the word entrepreneurship has been widely used, and the theory related to entrepreneurship has also developed rapidly. In real life, the rate of a team's entrepreneurial success is much higher than that of an individual, but there is no unify definition of the academic term of the "environmental team." Based on the domestic and international literature, Kamm, Shuman, Seeger, and Nurick (1990) believed that the entrepreneurial team refers to two or more individuals ${ }^{[1]}$, who participate in the enterprise's creation process with equal proportion of funds after conception and implementation ideas. Cooper and Dailier (1997) believed that, each member of the entrepreneurial team must has a substantial proportion of the funds and inputs that can be shared together ${ }^{[2]}$. Ensley, Carland, and Carland (1998) thought that people must meet three criterias before they become members of entrepreneurial team: (1) Establish a company together; (2) Have common financial interests; (3) Have a direct impact on the company's choice. The term of performance comes from management ${ }^{[3]}$. It was divided into individual and organizational performance. Generally, performance is considered to be the most effective output of activities carried out by the organization to achieve goals at different levels.

\subsection{Research status of entrepreneurial team performance}

Shi Lei (2008) conducted a comparative analysis of the diversified structure of entrepreneurial teams and found that different entrepreneurial teams have different effects on performance ${ }^{[4]}$. Zhang 
Zhenhua (2009) analyzed the impact of the competency of each dimension of the entrepreneurial team on the performance of the company by constructing the competency model of the entrepreneurial team ${ }^{[5]}$. Yu Shaozhong (2013) systematically expounded entrepreneurial performance research on the influencing factors of entrepreneurial team performance, measurement indicators, and evaluation methods from the theoretical perspective of entrepreneurial team performance research, and proposed an integrated model ${ }^{[6]}$. In summary, there have been many theoretical studies on entrepreneurial teams, but there were fewer studies based on entrepreneurial team performance, and there were lesser articles systematically analyzing the performance of entrepreneurial teams.

\section{Measurement indicators for entrepreneurial team performance}

The measurement of performance reflects the final goal of the activities. Different standards lead to different measurement methods, therefore we divided the performance assessment targets of entrepreneurial team by different perspectives.

According to the different dimensions, we can divide as single and multi-dimensional indicators. Murphy (1996) pointed out the analyzing result that 31 of 52 literatures in 1987 to 1993 used only one or two-dimensional performance analysis, and none of them used from five-dimensional to eight-dimensional ${ }^{[7]}$. The empirical comparative analysis showed that any measure of single-dimension performance cannot explain the difference in entrepreneurial research. Multi-dimensional performance used to measure a certain problem that face in business, and entrepreneurial performance is a multi-dimensional structure. Therefore, it is necessary to include the multiple one and carefully define the relationship between specific dimensions of performance and other variables and entrepreneurship that the research study focused on, which cannot be easily generalized to all dimensions of entrepreneurial performance.

Measurement strategies are divided into financial (short-term and long-term) and non-financial indicators. However, regarding to its certain limitations, for example, problems to define the overall level of efficiency (Chakravarthy, 1986), reflect the results of the past but not the future development, which give chances for non-financial indicators to be made up.

Table 1. Performance Evaluation Indicators for Entrepreneurial Teams

\begin{tabular}{|c|c|c|}
\hline & Target & Author \\
\hline \multirow{3}{*}{$\begin{array}{l}\text { Use only } \\
\text { financial } \\
\text { indicators }\end{array}$} & Annual sales & Obermayer \& Albach \\
\hline & $\begin{array}{l}\text { Short-term indicators: net sales margin, } \\
\text { total asset net margin } \\
\text { Long-term indicators: stock price, entry } \\
\text { value }\end{array}$ & Murray(1989) \\
\hline & Return on assets, profit before tax & Murphy(1996) \\
\hline \multirow[b]{2}{*}{$\begin{array}{l}\text { Use only } \\
\text { non-financial } \\
\text { indicators }\end{array}$} & Employee turnover rate & Boeker (2002) \\
\hline & $\begin{array}{l}\text { Five factors: whether to introduce new } \\
\text { products/services, whether there should } \\
\text { be new technologies, whether there should } \\
\text { be first-class (top quality) technology, } \\
\text { whether it should be innovative, and the } \\
\text { success rate of research and development. }\end{array}$ & Bell(2005) \\
\hline \multirow{2}{*}{$\begin{array}{l}\text { Combination } \\
\text { of two } \\
\text { indicators }\end{array}$} & $\begin{array}{l}\text { Return on assets, return on investment, } \\
\text { market volume of products, growth rate of } \\
\text { market share, customer satisfaction }\end{array}$ & $\begin{array}{l}\text { Venkatraman \& } \\
\text { Ramanujam } \\
\text { (1986) }\end{array}$ \\
\hline & $\begin{array}{l}\text { Return on assets, growth in market share, } \\
\text { profit before tax, sales revenue, employee } \\
\text { turnover and satisfaction, customer } \\
\text { satisfaction and loyalty }\end{array}$ & Murphy（1996） \\
\hline
\end{tabular}

Based on the above analysis, more and more scholars are beginning to lean forward 
comprehensive financial indicators and non-financial indicators. In fact, in the research of entrepreneurial performance evaluation indicators, researchers can determine appropriate entrepreneurial performance measurement indicators based on the theoretical perspective and the focus of entrepreneurial performance research, and combine analysis of influencing factors of entrepreneurial performance to form an entrepreneurial performance index system, which meets their own research.

\section{Influencing factors of entrepreneurial team performance}

\subsection{Entrepreneurial Team Conflict and Performance}

Conflicts are in opposition to friendship in human relationships. Traditionally, it can be divided into cognitive conflict and emotional conflict. Cognitive conflict that is, in order to solve the problems of the team, the members of the team questioned the decision-making activities, realize the sharing of knowledge, and ultimately formed the best solution. Emotional conflict is the personal conflict of team members that affects the overall decision of the team, which will ultimately reduce work efficiency or decision errors, thereby reducing the performance of the entrepreneurial team. Deutsch (1980) classified team conflicts into three categories based on different goal orientations : cooperative conflicts, confrontational conflicts, and concessional conflicts ${ }^{[13]}$. Collaborative conflicts are positively related to performance through innovation networks; adversarial conflicts are negatively related to team performance; concessional conflicts are irrelevant with performance; Yang Jun, Tian Li, Zhang Yuli, and Wang Weiyi (2010): empirical research basis on the Deutsh's conflict classification found that the various types of conflicts caused by heterogeneity determine the team's strategic innovation in different environments, which in turn affects the performance of the company $^{[14]}$.

\subsection{Entrepreneurship heterogeneity team and performance}

Early research on heterogeneity team was based on primarily demographic characteristics of team members. The individual's awareness of a group will seriously affect his perception, attitude and behavior. The research on the heterogeneity of entrepreneurial teams has expanded its scope and depth. With regard to the heterogeneity of the entrepreneurial team, including many aspects, this article mainly elaborates on the two aspects of knowledge heterogeneity and experience heterogeneity.

Knowledge heterogeneity. The way to realize the innovation process of knowledge and technology according to the relevant theories of knowledge view. Radan and Gahmic (2004) believed it has a great influence on the overall performance of the organization, and significant impact on innovation performance $^{[15]}$. Whereas, Ensley's (1998) research showed the negative relationship between entrepreneurial team heterogeneity and corporate growth, and the differences between team members' highest academic qualifications and functional background checks with corporate returns. Therefore, its impact on performance cannot be identified directly ${ }^{[3]}$, but together with the introduction of other mediation in further researches.

Experience heterogeneity. It researched and explored causal relationship between variables as new enterprise generation, opportunity discovery, resource acquisition, and new enterprise performance etc. Such knowledge is valuable, scarce, difficult to imitate, irreplaceable, and difficult to obtain. It is the complexity and uncertainty of entrepreneurial teams in the process of entrepreneurship.

\subsection{Entrepreneurial Team Competency and Performance}

Entrepreneurial team competency is a collection of individual member's internal ability to creative in the team. The individual competency of the team members can only be reflected in the completion of the team task. Ma Hongmin and Li Fei (2008) divided the competency characteristics into three dimensions: the competitiveness of entrepreneurial teams, which include opportunities, strategic capabilities, and relationship capabilities ${ }^{[16]}$; the development capabilities of entrepreneurial teams, include learning and innovation; the execution capabilities of entrepreneurial team, include 
organizational capabilities, conceptual capabilities, commitment capabilities, and collaboration capabilities. These three dimensions of competency affect the performance of the entrepreneurial team, and the environment plays a regulatory role. Zhang Zhenhua (2009) researched the relationship between competency and performance of entrepreneurial teams, and proposed eight dimensions of competency, namely entrepreneurial orientation, opportunity ability, relationship collaboration ability, organizational ability, commitment ability, learning ability, knowledge sharing, and innovation ability ${ }^{[5]}$.

\section{Evaluation of entrepreneurial performance}

Reasonable selection of assessment methods will help to improve the effectiveness and accuracy of entrepreneurial performance measurement results. Many scholars had conducted in-depth research on entrepreneurial performance measurement methods, and had mainly propose four different evaluation methods: objective evaluation method, subjective evaluation method, absolute evaluation method, and relative evaluation method. In order to understand these four evaluation methods more clearly, we further elaborate on Table 2.

Table 2. Comparison of Performance Measurement Methods for Entrepreneurial Teams

\begin{tabular}{|c|c|c|c|}
\hline & Meaning & Target & Features \\
\hline $\begin{array}{l}\text { Objective } \\
\text { Evaluation } \\
\text { method }\end{array}$ & $\begin{array}{l}\text { Methods for evaluating } \\
\text { entrepreneurial performance } \\
\text { using quantifiable and } \\
\text { objective indicators }\end{array}$ & $\begin{array}{l}\text { Return on } \\
\text { average assets, } \\
\text { sales return, } \\
\text { market share } \\
\text { and growth rate, } \\
\text { etc. }\end{array}$ & $\begin{array}{l}\text { Measurement result is } \\
\text { more objective and } \\
\text { accurate }\end{array}$ \\
\hline $\begin{array}{l}\text { Subjective } \\
\text { evaluation } \\
\text { method }\end{array}$ & $\begin{array}{l}\text { Impossible to use when } \\
\text { objective is evaluated }\end{array}$ & $\begin{array}{l}\text { New product } \\
\text { development } \\
\text { capabilities, } \\
\text { organizational } \\
\text { commitment, } \\
\text { service quality }\end{array}$ & $\begin{array}{l}\text { Only approximate } \\
\text { measurement results are } \\
\text { obtained, which are } \\
\text { subjective evaluations of } \\
\text { the degree and direction } \\
\text { of entrepreneurial } \\
\text { efficiency and } \\
\text { effectiveness. }\end{array}$ \\
\hline $\begin{array}{l}\text { Absolute } \\
\text { evaluation } \\
\text { method }\end{array}$ & $\begin{array}{l}\text { The Entrepreneurial } \\
\text { Enterprise's Entrepreneurial } \\
\text { Appraisal Performance } \\
\text { Method Based on the } \\
\text { Comparative Analysis of } \\
\text { Self-Employed Enterprises } \\
\text { by Using Objective Standard }\end{array}$ & $\begin{array}{l}\text { Own } \\
\text { endowments, } \\
\text { opportunity } \\
\text { costs, etc. }\end{array}$ & $\begin{array}{l}\text { To consider more control } \\
\text { variables, otherwise it is } \\
\text { sometimes difficult to } \\
\text { accurately determine the } \\
\text { merits of performance } \\
\text { without horizontal } \\
\text { comparison }\end{array}$ \\
\hline $\begin{array}{l}\text { Relative } \\
\text { evaluation } \\
\text { method }\end{array}$ & $\begin{array}{l}\text { Taking the performance of } \\
\text { main competitors in the same } \\
\text { industry as the frame of } \\
\text { reference, the method of } \\
\text { evaluating the } \\
\text { entrepreneurial performance } \\
\text { of the company through } \\
\text { comparison }\end{array}$ & $\begin{array}{l}\text { Competitor } \\
\text { performance } \\
\text { indicators }\end{array}$ & $\begin{array}{l}\text { It can not only eliminate } \\
\text { the interference of } \\
\text { external factors, but also } \\
\text { facilitate cross-industry, } \\
\text { cross-phase comparisons. }\end{array}$ \\
\hline
\end{tabular}

\section{Research insufficiency and future research}

In summary, although more and more scholars are trying to explore the characteristics of entrepreneurial teams and their impact on entrepreneurial performance from different perspectives, 
the "black box" of startup teams does not seem to fully opened yet, and research on entrepreneurial teams needs to be further in-depth research.

Therefore, in the future we should conduct in-depth discussions for the following three aspects. First, conduct empirical research on entrepreneurial team to distinguish the impact of entrepreneurial team, building in different industries on entrepreneurial performance. Second, the quantitative analysis of different cultural backgrounds, different leadership styles, emotional factors, resource integration capabilities, personnel composition diversification, and entrepreneurial performance are all future need to be studied in depth. Third, the crucial influence ability of the entrepreneurial team to performance is seen, but the source of the ability and the impact on the performance are all questions worth researching in the future.

\section{References}

[1] Kamm, J. B., Shuman, J. C., Seeger, J. A., \& Nurick, A. J. (1990). Entrepreneurial teams in new venture creation: a research agenda. Entrepreneurship Theory \& Practice, 14(4), 7-17.

[2] Cooper, A. C., \& Bruno, A. V. (1977). Success among high-technology firms. Business Horizons, 20(2), 16-22.

[3] M.D. Ensley, Carland, J. C., \& Carland, J. W. (1998). The effect of entrepreneurial team skill heterogeneity and functional diversity on new venture performance. Journal of Business \& Entrepreneurship, 10(1), 1-14.

[4] Shi Lei. (2008). On the Choice Model and Standard of Entrepreneurial Team Composition. Foreign Economy \& Management, 30(4), 52-58.

[5] Zhang Zhenhua. (2009). Research on the Relationship between Competency Structure and Entrepreneurial Performance of Entrepreneurial Teams. Contemporary Economic Research, 12(1), 22-25.

[6] Yu Shaozhong. (2013). A Review of Entrepreneurial Performance Research. Foreign Economy \& Management, 35(2), 34-42.

[7] Murphy, G. B., Trailer, J. W., \& Hill, R. C. (1996). Measuring performance in entrepreneurship research. Journal of Business Research, 36(1), 15-23.

[8] Chakravarthy, B. S. (1986). Measuring strategic performance. Strategic Management Journal, 7(5), 437-458.

[9] Murray, A. I. (2010). Top management group heterogeneity and firm performance. Strategic Management Journal, 10(S1), 125-141.

[10] Boeker, W., \& Karichalil, R. (2002). Entrepreneurial transitions: factors influencing founder departure. Academy of Management Journal, 45(4), 818-826.

[11] Bell, Geoffrey G. (2010). Clusters, networks, and firm innovativeness. Strategic Management Journal, 26(3), 287-295.

[12] Venkatraman, N., \& Ramanujam, V. (2014). Measurement of business performance in strategy research: a comparison of approaches. Asia-Pacific Journal of Risk and Insurance, 11(4), 801-14.

[13] Festinger, L. (1980). Retrospections on social psychology. Retrospections on social psychology. Oxford University Press.

[14] Yang Jun, Tian Li, Zhang Yuli, Wang Weiyi. (2010). Innovation or Imitation: The Role of Heterogeneity and Conflict Features in Entrepreneurial Teams. Management World, 3(3), 84-96.

[15] Rodan, S., \& Galunic, C. (2004). More than network structure: how knowledge heterogeneity influences managerial performance and innovativeness. Strategic Management Journal, 25(6), 541-562.

[16] Ma Hongmin, Li Fei. (2008). Discussion on the Relationship between Entrepreneurial Team Competency and Entrepreneurial Performance. Modern Management Science, 12(1), 45-46. 